Marquette University

e-Publications@Marquette

Finance Faculty Research and Publications

Business Administration, College of

$1-1-2017$

\title{
A Survey of Litigation in Corporate Finance
}

Matteo Arena

Marquette University, matteo.arena@marquette.edu

Stephen P. Ferris

University of Missouri - Columbia

Accepted version. Managerial Finance, Vol. 43, No. 1 (2017): 4-18. DOI. (C) 2017 Emerald Publishing Limited. Used with permission. 


\section{A Survey of Litigation in Corporate Finance}

Matteo Arena

College of Business and Administration, Marquette University, Milwaukee, WI

Stephen Ferris

Trulaske College of Business, University of Missouri, Columbia, MO

\section{Abstract:}

Purpose: The purpose of this paper is to review research on litigation in corporate finance.

Design/ methodology/ approach: This paper surveys studies on the estimation of litigation risk, litigation costs, stock reaction to lawsuit announcement, and the effect of litigation on corporate financial policies and outcomes.

Findings: The first section presents a survey of studies that estimate litigation risk. The authors then discuss a set of studies that focus on the various costs associated with litigation. The third area of review is 
about studies which estimate the market reaction to a lawsuit announcement. The next section surveys studies that examine the relation between litigation and a variety of corporate policies, behaviors, and outcomes. The authors then discuss the emerging literature on how corporate political connections can influence the outcome of litigation. The survey concludes with a brief summary and a discussion of suggestions for future research involving corporate litigation.

Originality/ value: By providing an extensive review of the literature on litigation in corporate finance, this survey can help researchers to identify recent trends in litigation research and select promising new avenues of investigation in the field.

Keywords: Corporate finance, Litigation

\section{I ntroduction}

While corporate litigation has always been present in the corporate environment, it has lately evolved into a major source of risk to the firm. Despite the enactment of the Private Securities Litigation Reform Act of 1995 (PSLRA), which was designed to curb frivolous lawsuits, the number of corporate lawsuits has increased by more than 50 percent and corporate litigation costs have more than doubled over the past decade. $\underline{1}$ The total amount of settlements in class action security lawsuits has increased from \$150 million in 1997 to $\$ 9.7$ billion in 2005 (Zingales, 2007). As litigation risk and costs have increased, the study of their effects on firm value and activities has become more critical than ever.

Litigation in corporate finance is of great interest and worthy of investigation largely because its cost-benefit trade-off for the firm stakeholders is unclear. While litigation costs are significant, settlement amounts in some cases provide only payments of attorney's fees and do not generate any direct benefit to plaintiff stakeholders (Romano, 1991). Many lawsuits, however, have a beneficial role because, by imposing monetary and reputational costs to the firm, provide external disciplining of managers and can help to reduce agency problems within the firm (Becht et al., 2003).

Managerial Finance, Vol 43, No. 1 (2017): pg. 4-18. DOI. This article is @ Emerald and permission has been granted for this version to appear in e-Publications@Marquette. Emerald does not grant permission for this article to be further copied/distributed or hosted elsewhere without the express permission from Emerald. 
While a few studies on the costs of corporate litigation and the effect of lawsuits on firm value began to appear in the academic press in the late 1970s and early 1980s, the creation of the Class Action Security Lawsuit Database in the late 1990s and the Audit Analytics Litigation Database in the 2000s allowed the generation of a large number of empirical studies of the effects of litigation in corporate finance. In this literature survey, we provide a review of the litigation literature in corporate finance organized by different topic areas. Section 2 presents a survey of studies that estimate litigation risk. Section 3 discusses a set of studies that focus on the costs associated with litigation. Section 4 reviews event studies on the market reaction to the announcement of lawsuits. Section 5 surveys studies that examine the relation between litigation and a variety of corporate policies, behaviors, and outcomes. Section 6 discusses the emerging literature on how corporate political connections can influence the outcome of litigation. Section 7 concludes with a brief summary and a discussion of future areas of research involving corporate litigation.

\section{Determinants and estimation of litigation risk}

One of the most common measures of litigation risk is an ex ante proxy set as an indicator variable equal to one for firms becoming defendant of a lawsuit in the following year and zero otherwise (e.g. Lowry and Shu, 2002; Field et al., 2005; Arena and Julio, 2015). By analyzing firms during the fiscal year preceding the lawsuit filing, this litigation risk dummy provides a proxy of ex ante litigation risk and can be used to pursue two different research tracks. The first is to build predictive models of corporate litigation while the second is ex post in nature and seeks to explain why firms are sued.

A large component of litigation risk for corporations is industry based. Francis et al. (1994a, b), find that firms in the biotechnology, computers, electronics, and retail industries had the highest incidence of litigation between 1988 and 1992. They create a proxy of litigation risk as an indicator variable based on affiliation in these four industries using SIC codes. Several studies use this simple industry indicator as proxy for litigation risk (i.e. Ali and Kallapur, 2001; Ц ohnson et al., 2000a, 2001, 2007). Chandra et al. (2004) and Choi (2006) uses a variation of this litigation proxy by excluding retail firms and restricting

Managerial Finance, Vol 43, No. 1 (2017): pg. 4-18. DOI. This article is (C) Emerald and permission has been granted for this version to appear in e-Publications@Marquette. Emerald does not grant permission for this article to be further copied/distributed or hosted elsewhere without the express permission from Emerald. 
their analysis to firms belonging to the three high technology industries used by Francis et al. (1994a, b) (i.e. computer hardware, computer software, and pharmaceuticals). Kim and Skinner (2012), however, show that these industry measures of litigation risk have low predictive power. They find that while litigation tends to cluster in certain industries, the set of industries varies over time.

As shown by Kim and Skinner (2012), the addition of firm characteristics to an industry indicator significantly increases the predictive power of future lawsuits. This more sophisticated measure of litigation risk, which includes firm-specific and in some cases industry-wide factors, is the product of logit or probit regression models of litigation. These models use the predicted probabilities generated by a binary choice regression as measure of litigation risk. The explanatory variables of these regressions consist of firm characteristics that are related to the incidence of litigation. Typical variables of these models are market capitalization, stock returns, stock volatility, and stock turnover as well as industry indicator variables consistent with Francis et al. (1994a, b). Market capitalization is related to the risk of litigation as larger companies are more likely to settle with higher payments to plaintiffs. This makes them more attractive as targets for lawsuits. Stock performance variables are related to the incidence of security class action lawsuits since such suits are often triggered by large stock price declines, high stock volatility, or excessive turnover surrounding the period of the alleged fraud (Alexander, 1991; Jones and Weingram, 1996; Skinner, 1997; Dyl, 1999; Simmons and Hoyt, 1993; Gande and Lewis, 2009).

Studies such as Johnson et al. (2000a) and J ohnson et al. (2007) include additional explanatory variables such as stock beta, return skewness, insider trading, external financing, CEO power, and management monitoring. Insider trading and high external financing activity might be used to exploit high stock valuation obtained through misleading releases of information, activities that increase the risk of litigation (Brown et al., 2005). Dechow et al. (1996) include a CEO power variable because CEOs with greater power are more likely to engage in the opportunistic behaviors that can trigger litigation.

Better monitoring of management and stronger corporate governance can reduce the incidence of litigation. Daines et al. (2010)

Managerial Finance, Vol 43, No. 1 (2017): pg. 4-18. DOI. This article is @ Emerald and permission has been granted for this version to appear in e-Publications@Marquette. Emerald does not grant permission for this article to be further copied/distributed or hosted elsewhere without the express permission from Emerald. 
include corporate governance and transparency ratings variables, but fail to find these variables having predictive power for litigation. Kim and Skinner (2012) show that corporate governance and managerial opportunism variables do not significantly add to the predictive ability of binary choice regression models of litigation risk.

A few studies analyze the influence of earnings manipulation and disclosure quality on litigation risk. Firms that manipulate earnings upward prior to stock issues are more vulnerable to litigation (DuCharme et al., 2004). The incentive compensation mix for executives has also an effect on litigation risk by increasing the probability of earnings manipulation (Peng and Roell, 2008). Companies that issue earning warnings are in certain cases able to deter lawsuits (Field et al., 2005).

Brown et al. (2005) and Rogers and Stocken (2005) include industry dummies to their litigation probability model in addition to many of the variables mentioned above. Predictive models that include firm characteristics with industry indicator variables are the most complete and offer the stronger predictive power (Kim and Skinner, 2012).

Recently, the literature on litigation risk has begun investigating the role of behavioral factors on lawsuit initiations. Hutton et al. (2015) find that firms with opposing political values face different types of lawsuits. Republican-leaning firms are more likely to be exposed to labor, civil rights, and environmental lawsuits, while Democratic-leaning firms are more likely to be exposed to securities and intellectual property lawsuits. Banerjee et al. (2016) find that executive overconfidence increases the likelihood of securities class action lawsuits.

Adhikari et al. (2016) report that firms with female executives experience lower litigation risk.

Directors and officers ( $D \& O$ ) liability insurance coverage provides an alternative proxy for litigation risk. Companies purchase D\&O liability insurance to provide personal coverage and corporate reimbursement if a claim is settled with no admission of bad faith or there is no finding of bad faith in court. One advantage of this proxy is

Managerial Finance, Vol 43, No. 1 (2017): pg. 4-18. DOI. This article is (C) Emerald and permission has been granted for this version to appear in e-Publications@Marquette. Emerald does not grant permission for this article to be further copied/distributed or hosted elsewhere without the express permission from Emerald. 
that it is able to capture litigation risk for firms that successfully avoid litigation even though they might be highly exposed to the risk of a lawsuit. Unfortunately, data on D\&O insurance for US firms are not publicly available and only a few studies have been able to use this proxy of litigation risk in relation to corporate governance, the quality of financial reporting and earnings forecasts (i.e. Baker and Griffith, 2007; Cao and Narayanamoorthy, 2011, 2014).

While there is extensive research on litigation risk factors in the USA, little is known about litigation risk at the international level. Arena and Ferris (2016) explore factors that affect litigation risk around the world and find that defendant firms headquartered in civil law countries and in countries with less efficient legal and judiciary systems face lower litigation risk. Unlike US-centric litigation risk studies, Arena and Ferris (2016) do not find a significant relation between stock turnover, cumulative returns, and the probability to be sued.

\section{Litigation costs}

Lawsuits often result into significant costs for the sued firms. Corporate lawsuits have significant direct costs with large negative effects on profitability, cash holdings, and firm value. The direct costs consist of settlement disbursements or damages and legal fees. Some of the direct costs of litigation are defrayed by litigation insurance. Almost all US publicly traded firms buy personal coverage insurance (A-side insurance) and corporate reimbursement coverage insurance for director and executive indemnification reimbursement (B-side insurance). Many firms also purchase optional entity securities coverage ( $\mathrm{C}$-side insurance) which provides protection to the corporation from its own liability. C-side litigation insurance, however, frequently does not provide full coverage. According to the 1996-2006 Towers Perrin D\&O Liability Surveys, publicly traded firms have an average litigation insurance limit of about $\$ 15$ million. This amount only covers about 26 percent of the average settlement disbursement reported by Arena and Julio (2015) for their sample in the same period (\$56 million). ${ }^{2}$ Settlement amounts are positively related to the severity of the case (Cox and Thomas, 2004) and the magnitude of shareholder losses (Karpoff et al., 2008a). Securities class actions with

Managerial Finance, Vol 43, No. 1 (2017): pg. 4-18. DOI. This article is (C) Emerald and permission has been granted for this version to appear in e-Publications@Marquette. Emerald does not grant permission for this article to be further copied/distributed or hosted elsewhere without the express permission from Emerald. 
institutional owners as lead plaintiffs have larger monetary settlements than lawsuits with individual lead plaintiffs (Cheng et al., 2010).

Before the PSLRA of 1995, 20 percent of the cases resolved into settlements that exceeded 10 percent of the firm's annual revenues (Skinner, 1997). Cutler and Summers (1988) examine the Pennzoil/Texaco lawsuit and find significant costs associate with the lawsuit, with the losses for Texaco being larger than the gains for Pennzoil.

They find that the combined decline in value for the two firms is about $\$ 2$ billion and attribute the majority of this drop to an increase in the costs of financial distress for Texaco. Engelmann and Cornell (1988) study the wealth implications around filings, verdicts, and settlements for a sample of five interfirm lawsuits. They also observe combined wealth losses for the litigating firms.

On December 22, 1995, Congress enacted the Private Securities Litigation Reform Act of 1995, which added Section 27(a)(3) to the Securities Act of 1933 and Section 21D(a)(3) to the Securities Exchange Act of 1934. This act added obstacles to securities fraud class action lawsuits to reduce the incidence of frivolous litigation. The new rules include a revised lead plaintiff appointment process, the prohibition of bonus payments to lead plaintiffs, the reduction of attorneys' fees to a "reasonable percentage" of any damage award, the comprehensive disclosure of the provisions of settlement and attorney's fees, the change from "joint and several liabilities" to "proportionate liability," a higher pleading standard to increase the cost of lawsuits; and a 90-day "bounce back" rule to prevents case from rushing into courts. Grundfest and Perino (1997) find that number of class action security decreased by about 16 percent the year of the Act compared to the year before. Bajaj et al. (2014) report that even though the number of state cases increased between 1995 and 1996, the number of total cases declined by 25 percent due to a drop of about 35 percent in the number of federal cases during the same period. Perino (2003) extends the analysis up to 2001 and obtain results consistent with previous researchers. Ferris and Pritchard (2001) and Johnson et al. (2007) determine that the PSLRA has significantly decreased the number of frivolous shareholder lawsuits in the years following the enactment of the act. As we note in

Managerial Finance, Vol 43, No. 1 (2017): pg. 4-18. DOI. This article is @ Emerald and permission has been granted for this version to appear in e-Publications@Marquette. Emerald does not grant permission for this article to be further copied/distributed or hosted elsewhere without the express permission from Emerald. 
the introduction to this survey, however, after an initial decline, the number of lawsuits has resumed its growth. Moreover, settlement costs have not decreased following the passage of the Reform Act (Karpoff et al., 2008a).

In addition to settlement disbursements and attorney's fees, firms sustain indirect litigation costs that in most circumstances have a stronger detrimental effect on shareholder and debtholder value than direct costs. Indirect costs include loss of firm's credibility, increase in the perceived uncertainty about a firm's prospects, loss of customers and suppliers, and diversion of manages' time and resources (Karpoff and Lott, 1993, 1999; Phillips and Miller, 1996; ЦLhnson et al., 2000a, b; Black et al., 2006). As discussed by Klein and Leffler (1981) and Jarrell and Peltzman (1985), the revelation of misconduct have significant effects on corporate costs and operations. Overall, direct and indirect costs greatly exceed the expected befits accrued to the plaintiffs (Engelmann and Cornell, 1988).

Karpoff et al. (2008a) estimate the reputational losses sustained by firms prosecuted for financial misrepresentation by using a modified version of the empirical procedure introduced by Peltzman (1981). They find that the reputation loss exceeds the legal penalty by more than 7.5 times. The reputation loss is larger for firms that rely more on implicit contracts (e.g. firms with larger $R \& D$ expenditures and intangible assets) consistent with Klein and Leffler (1981) and Landes and Posner (1987). Murphy et al. (2009) empirically show that losses in market value upon revelation of corporate misconduct are partially due to higher firm risk and lower future profitability.

\section{Stock market reaction at the time of lawsuit filings}

The earliest law and finance studies concerning corporate litigation focus on the stock price reaction of defendant firms at specific times during the lawsuit process. Ellert (1976) examines the market reaction to announcements of legal challenges to mergers by the Federal Trade Commission and the Department of J ustice in the 1950s and 1960s. He finds that, in the month following the lawsuit filing, the defendant firm's stock price declines on average by 2

Managerial Finance, Vol 43, No. 1 (2017): pg. 4-18. DOI. This article is (C) Emerald and permission has been granted for this version to appear in e-Publications@Marquette. Emerald does not grant permission for this article to be further copied/distributed or hosted elsewhere without the express permission from Emerald. 
percent. Fischel and Bradley (1986) analyze the stock price reaction at the time of a judgement on management motions to dismiss in derivative suits and discovers a significantly negative return when lawsuits are dismissed. This suggests that the market views derivative lawsuits positively. Romano (1991) presents the first event study on lawsuit filings focusing on a random sample of publicly traded firms sued between 1966 and 1987. She does not observe any significant abnormal returns for lawsuit initiations.

Subsequent evidence, however, consistently shows that the stock market reacts negatively to the filing of corporate lawsuits. Karpoff and Lott (1993) explore a sample of corporate defendants accused of fraud. They determine that such firms sustain significant market losses at the announcement of the accusation. The authors attribute most of this stock price decline to reputation costs. Bhagat et al. (1994) perform an event study on interfirm litigation, lawsuits in which both the plaintiff and the defendant are corporations. They find joint wealth losses at the time of the lawsuit filing and show that these stock price declines are mainly due to an increased probability of financial distress for the defendant firm. In a subsequent study, Bizjak and Coles (1995) focus on a subset of interim lawsuits (i.e. private antitrust suits). They determine that joint wealth effects at the time of the lawsuit filing are negative. They further explain that the decline in the stock price in antitrust disputes are attributable to the expectation of court restrictions on the defendant's business practices and the likelihood of additional suits and financial distress. Bizjak and Coles (1995) also find a positive stock market reaction for plaintiff firms upon at the time of the lawsuit initiation.

Bhagat et al. (1998) examine the wealth effects of all types of corporate lawsuits filed between 1981 and 1983. They report that regardless of the identity of the entity or individual that brought the lawsuit against a firm (i.e. government entity, another firm, or a private citizen), the defendant firm's stock price experiences a statistically significant decline upon the lawsuit filing.

Gande and Lewis (2009) examine a comprehensive sample of security class action lawsuits filed between 1996 and 2003 and confirm significantly negative stock price reactions at the announcement. They also find that shareholders partially anticipate these lawsuits based on

Managerial Finance, Vol 43, No. 1 (2017): pg. 4-18. DOI. This article is (C) Emerald and permission has been granted for this version to appear in e-Publications@Marquette. Emerald does not grant permission for this article to be further copied/distributed or hosted elsewhere without the express permission from Emerald. 
lawsuits against other firms in the same industry and capitalize some of these losses prior to the lawsuit filing date. Klock (2015)

investigates a sample of class action lawsuits between 1995 (the year of the enactment of the PSLRA) and 2012 and obtains results consistent with those of Gande and Lewis (2009).

Bhattacharya et al. (2007) study the stock market reaction to lawsuit filings for non-US firms sued in US courts. They find that nonUS firms sustain larger stock market losses at the announcement, which is a rational adjustment to their higher probability to lose in comparison to US defendant firms.

\section{The effect of litigation on corporate behavior, decisions, and outcomes}

Litigation risk and lawsuits have significant long-lasting effects on the defendant firm, its executives and directors. The law and finance literature provides an extensive examination of the ramification of corporate litigation on a large number of corporate activities, policies, behaviors, and outcomes such as equity issuance and IPO underpricing, debt financing, cost of capital, corporate governance, investment decisions, and insider trading. In the following sections we survey studies in each of these areas.

\subsection{Equity issuance and IPO underpricing}

The Securities Acts of 1933 and 1934 provides shareholders the right to sue a firm going public (i.e. an IPO) for material misstatements or omissions. The great majority of IPO lawsuits against the issuing firms are brought under Sections 11 and 12 of the Securities Act of 1933 and Section 10(b) of the Securities Act of 1934 (Lowry and Shu, 2002). Under Section 11, damages for direct purchasers of IPO stocks depend on the difference between the offer price and either the sale price or the security's price at the time of the lawsuit. Aftermarket purchasers can also sue the IPO firm if they can demonstrate that they relied on the prospectus to make their purchasing decision. Because damages are directly related to the offer price, a firm that underprices its IPO more aggressively has lower potential damages and a decreased probability of being sued. A

Managerial Finance, Vol 43, No. 1 (2017): pg. 4-18. DOI. This article is (C) Emerald and permission has been granted for this version to appear in e-Publications@Marquette. Emerald does not grant permission for this article to be further copied/distributed or hosted elsewhere without the express permission from Emerald. 
possible motivation for IPO underpricing is, therefore, to reduce litigation risk. 3

Litigation risk is one of the main long-standing explanations of underpricing along with the signaling and information asymmetry hypotheses. Ibbotson (1975) is the first to posit that IPO firms underprice their shares to protect themselves from the risk of litigation. Tinic (1988) formulates a model of the expected cost of legal liabilities as a function of the difference between the offer price and the post-offer price. Hughes and Thakor (1992) further develop Tinic's model in a game-theory setting and specify the conditions to reach equilibrium in underpricing. Hensler (1995) offers another variation of Tinic's theory by developing a utility maximization singleperiod model.

Several empirical studies test these theoretical models. Tinic (1988) compares underpricing before the 1933 Securities Act (i.e. 1923-1930) with underpricing after the enactment of the Act (i.e. 1966-1970). He discovers that underpricing is significantly higher in the later period which is consistent with the litigation risk hypothesis of underpricing. Drake and Vetsuypens (1993), however, report that the average initial returns between 1972 and 1977 are actually lower than those before 1933. They argue that Tinic's results might be driven by factors other than litigation risk. Keloharju (1993) test different underpricing hypotheses in the Finnish stock market. He finds a mean underpricing of 8.7 percent, which is significantly lower than that for US IPO firms during the same period. He concludes that, because IPO litigation in Finland is virtually non-existent, the difference in underpricing can be at least partially explained by litigation risk. Drake and Vetsuypens (1993) find that IPO firms with positive initial returns are more likely to be sued than firms with negative returns. Even though their result is inconsistent with the litigation risk hypothesis, the validity of their conclusion is challenged by potential endogeneity. 4 Lowry and Shu (2002) use a simultaneous equation model to control for the endogeneity between litigation risk and underpricing that affected previous studies. Their results show that underpricing has both an insurance and a deterrence effect on litigation. Firms with higher litigation risk underprice their IPOs more to reduce the risk of being sued and a more pronounced underpricing reduces expected litigation costs.

Managerial Finance, Vol 43, No. 1 (2017): pg. 4-18. DOI. This article is (C) Emerald and permission has been granted for this version to appear in e-Publications@Marquette. Emerald does not grant permission for this article to be further copied/distributed or hosted elsewhere without the express permission from Emerald. 
Following the bust of the internet bubble in the early 2000s, a multitude of IPO allocation lawsuits were filed in the Southern District Court of New York against investment banks that underwrote IPOs in the previous three years. Zhu (2009) analyses 259 IPO allocation cases involving 28 percent of the 906 firms that went public between 1998 and 2000. Unlike traditional Section 11 IPO lawsuits, allocation lawsuits charge underwriters for an excessive increase in aftermarket prices. IPOs with higher underpricing, therefore, are more likely to trigger allocation lawsuits. Zhu (2009) finds that, because the predominance of this type of IPO lawsuits in the early 2000s, deeper underpricing did not reduce litigation risk during that specific period. Hao (2011) does not observe firms with higher litigation risk underpricing their IPOs more during her sample period of 1995-2005. She finds, however, that firms which are more likely to withdraw their offerings face higher litigation risk if they complete the IPO. Further, she reports that firms with higher litigation risk pay a higher gross spread to their underwriters. Walker et al. (2015) posit that plaintiffs of IPO lawsuits manifest opportunistic behavior. They find that the main predictors of litigation and settlement amounts are the monetary damages that plaintiffs can claim and the remaining wealth available in the firm. Hanley and Hoberg (2012) perform a word content analysis on IPO prospectuses and find a trade-off between underpricing and disclosure as hedges against litigation. While strong disclosure is an effective hedge against all types of IPO lawsuits, underpricing is effective mainly in preventing Section 11 litigation. Ferris et al. (2013) use textual analysis to examine the incidence of conservatism in a set of IPO prospectuses over 1999-2005. They determine that auditor stature is positively related to prospectus conservatism. They conclude that more reputable auditors tend to encourage issuer conservatism, perhaps in response to reputation concerns and concern over legal liability.

Recently researchers have begun to analyze the relation between litigation risk and IPO underpricing at the international level using a cross-country framework. Banerjee et al. (2011) and Lin et al. (2013), consistent with the litigation risk hypothesis of underpricing, find that higher litigation risk in a specific country the larger is associated with greater underpricing of the IPOs in that country.

Managerial Finance, Vol 43, No. 1 (2017): pg. 4-18. DOI. This article is @ Emerald and permission has been granted for this version to appear in e-Publications@Marquette. Emerald does not grant permission for this article to be further copied/distributed or hosted elsewhere without the express permission from Emerald. 


\subsection{Cost of capital}

Due to its significant direct and indirect costs, corporate litigation has an important effect on the defendant firm's cost of capital. Firms that are subject to accounting enforcement actions by the SEC experience a significant increase in their cost of capital (Dechow et al., 1996). Following a lawsuit filing or revelation of corporate misconduct, the defendant firm's stock tends to experience an increase in idiosyncratic volatility. This has a consequent effect on the firm's cost of capital (Murphy et al., 2009). Chava et al. (2010) report that, at the time of a filing of a class action lawsuit, the defendant firm's cost of equity capital significantly increases and that this increase is incremental over the effect of the disclosure announcement. They also find that accounting fraud lawsuits and lawsuits with high merit have a stronger effect on cost of capital.

Both at the time when firms experience litigation risk and after the filing of a litigation, firms sustain higher interest on their bank loans. Banks price litigation risk in loan contracting by charging a higher spread, offering shorter maturity loan, or loans with more covenants to firms with higher likelihood to be sued (Yuan and Zhang, 2015). Following the filing of a class action security lawsuit, defendant firms experience an increase in loan spreads, higher up-front borrowing charges, and more financial covenants and collateral requirements (Deng et al., 2014). When corporate directors are more insulated from potential litigation due to limited liability and indemnification provisions, firms benefit from higher credit ratings and lower yield spreads (Bradley and Chen, 2011).

\subsection{Corporate financial policies}

Recently the finance literature has started investigating the effect of litigation on corporate financial policies. Corporate managers are likely to manage expected future litigation costs by modifying financial policies. Arena and Julio (2015) find that firms significantly increase the level of their cash holdings in anticipation of lawsuits. The market value of cash is significantly lower for firms exposed to litigation risk. One mechanism through which firms accumulate cash is by reducing corporate investments. Conversely, firms that overinvest

Managerial Finance, Vol 43, No. 1 (2017): pg. 4-18. DOI. This article is @ Emerald and permission has been granted for this version to appear in e-Publications@Marquette. Emerald does not grant permission for this article to be further copied/distributed or hosted elsewhere without the express permission from Emerald. 
are more likely to get sued (McTier and Wald, 2011). Firms with a higher risk of costly lawsuits are more likely to undertake aggressive growth through acquisitions to diversify their risk (Gormley and Matsa, 2011).

The full implications of litigation on firm value and liquidity are only known at the time of the lawsuit resolution. Firms, therefore, are likely to further adjust financial policies at the time of a lawsuit settlement. Arena and Julio (2016) show that firms set their pay out policy based on the perceived litigation risk and then change their share repurchase policy once the lawsuit is resolved. Firms that face significant litigation risk pay lower dividends or omit dividends while distributing more cash through share repurchase programs. This increase in pay out flexibility allows firms to more easily decrease cash distributions to shareholders if anticipated litigation expenses are subsequently incurred. McTier and Wald (2011) also find that firms reduce pay outs following a lawsuit. In addition firms are likely to reduce overinvestment activity, cash holdings, and diversification postsuit. Autore et al. (2014) discover that firms tend also to reduce their reliance on debt and equity financing following severe litigation episodes.

\subsection{Financial reporting}

The accounting literature has extensively explored the effect of litigation on financial reporting and disclosure. We report a brief overview of the main studies on this issue due to the important influence that financial reporting has on many corporate financial decisions and outcomes.

The early empirical evidence on the effect of financial disclosure and litigation risk is mixed. While Skinner (1994) states that voluntary earnings releases can decrease the risk of litigation, Francis et al. $(1994 a, b)$ determine that early disclosure increases a firm's legal exposure.

There are several reasons why earnings warnings can reduce the probability of a lawsuit. Timely disclosure reduces the time the stock trades at inflated prices, which in turn leads to a reduced incentive for plaintiffs to sue or lower settlements. Early disclosure

Managerial Finance, Vol 43, No. 1 (2017): pg. 4-18. DOI. This article is (C) Emerald and permission has been granted for this version to appear in e-Publications@Marquette. Emerald does not grant permission for this article to be further copied/distributed or hosted elsewhere without the express permission from Emerald. 
weakens the claim that the firm withheld information and can also decrease contingent lawsuit loss (Skinner, 1994, 1997). Francis et al. (1994a, b), however, empirically observe that earnings warnings are likely to be followed by class action securities lawsuits. Their results, however, have been received with scepticism due to possible endogeneity. Firms with bad news are concurrently likely to disclose them and to be sued. The spurious relation between disclosure and lawsuits has the effect of concealing the lawsuit deterrence effect of disclosure (Skinner, 1997; Field et al., 2005). Field et al. (2005) employ a simultaneous equations method and find that disclosure deters litigation rather than triggering it. By employing a new measure of the timeliness of earnings news, Donelson et al. (2012) obtain similar results. After the resolution of a lawsuit, defendant firms tend to reduce the level of information disclosed to investors ( $\$ ohnson et al., 2001; Rogers and Van Buskirk, 2009). Rogers et al. (2011) examine the tone of disclosure through a textual analysis and find that companies which are unusually optimistic in their earnings announcements or in which managers engage in abnormal selling are more likely to be targets of lawsuits.

\section{5 Corporate governance}

Litigation has also a significant effect on internal governance mechanisms. Romano (1991) finds that managerial turnover is more frequent for firms involved in litigation. While Agrawal et al. (1999) and Helland (2006) do not find unusual turnover among executives and directors of firms charged with fraud, Niehaus and Roth (1999) show that lawsuits that terminate with large settlements are likely to result in CEO turnover. Similarly, executives that are found guilty of financial misrepresentation by the Security and Exchange Commission and the Department of J ustice are almost always removed from their position and bear significant financial losses (Karpoff et al., 2008b). Security class action lawsuits increase the likelihood that the CEO will suffer a reduction in compensation or be laid off, and increase the likelihood that the firm will receive a disciplinary takeover bid (Humphery-Jenner, 2012).

Outside board directors do not face abnormal turnover in firms involved in litigation, but they tend to lose a significant number of

Managerial Finance, Vol 43, No. 1 (2017): pg. 4-18. DOI. This article is @ Emerald and permission has been granted for this version to appear in e-Publications@Marquette. Emerald does not grant permission for this article to be further copied/distributed or hosted elsewhere without the express permission from Emerald. 
board seats held in other firms (Fich and Shivdasani, 2007). The monitoring quality of boards of directors significantly improves following the filing of derivative lawsuits. In particular, the number of independent directors increases following derivative litigation (Ferris et al., 2007). Similarly, after being involved in a fraud case, firms take actions to improve their governance practices by increasing the number of independent directors and audit committee meetings. Both operating and stock performance improve after these changes (Farber, 2005; Marciukaityte et al., 2006). The improvement in board independence is especially significant when institutional investors serve as lead plaintiff in the security class action lawsuit (Cheng et al., $\underline{2010)}$.

While the evidence discussed above views litigation as an effective external force to improve internal governance practices, some studies present evidence that suggests that litigation in some cases can have the effect of increasing agency conflicts. Peng and Roell (2008) show that incentive compensation with stock options encourages firms to manipulate earnings during litigation class periods. During that time executives exercise more options and sell more shares. Dai et al. (2014) find that pay-for-performance sensitivity decreases after the announcement of a lawsuit filing, but reverts back to its original level after the resolution of the lawsuit. Gormley and Matsa (2011) find that firms with employees exposed to newly identified carcinogens respond to the increase in litigation risk by growing through diversifying acquisitions, which on average are associated with negative announcements returns.

\subsection{Insider trading}

Niehaus and Roth (1999) analyze a small sample of class action lawsuits between 1988 and 1994 and do not find abnormal insider trading activity during the class action period. Later studies on larger samples, however, do provide evidence of insider trading surrounding lawsuits. Griffin et al. (2004) determine that during the class action period net insider sales are significantly higher than that for insiders of matched non-sued firms. I qbal et al. (2007) find evidence of insider trading prior to the filing of a lawsuit. Bradley et al. (2014) report that managers significantly increase their informed option exercise during

Managerial Finance, Vol 43, No. 1 (2017): pg. 4-18. DOI. This article is @ Emerald and permission has been granted for this version to appear in e-Publications@Marquette. Emerald does not grant permission for this article to be further copied/distributed or hosted elsewhere without the express permission from Emerald. 
the class period. Overall, excluding Niehaus and Roth (1999), all research on litigation and insider trading provides evidence of managers exploiting private information around security lawsuit events and therefore supports the merits of security class action litigation.

\section{Litigation and the politically connected firm}

The extent to which politically connected firms benefit while in the process of litigation represents yet another area with implications for corporate finance. Correia (2014) studies SEC initiated lawsuits and reports that politically connected firms face less litigation risk and are awarded lower penalties. Firth et al. (2011) conclude that there is a favorable bias toward politically connected firms in the Chinese court system. Fulmer and Knill (2013) find that CEOs who contribute to PACs receive reduced penalties when prosecuted by the Securities and Exchange Commission or the Department of J ustice. Abdulmanova (2016) examines federal and state political connections for a large sample of US firms and concludes that such influence helps to decrease the losses associated with federal class action litigation.

\section{Summary and directions for future research}

As noted in this survey, the issue of corporate litigation is one of increasing importance to the modern firm. Its importance resides in the fact that litigation has the ability to influence essentially every aspect of the firm's operations. Indeed, we have described how litigation can influence equity issuance decisions, the firm's cost of capital, financial reporting, and corporate governance. The consequence of its effect on firm value and profitability is vast. These effects of litigation justify its importance as a subject for academic study.

The academic literature in this area is exceptionally interdisciplinary. The litigation area itself is organic to law, but because of its effect on the firm's activities, it has expanded to include finance, management, accounting, and economics. Because much of the litigation literature focuses on an understanding of why firms are sued, there is also extensive work appearing in the psychology and political science literatures.

Managerial Finance, Vol 43, No. 1 (2017): pg. 4-18. DOI. This article is (C) Emerald and permission has been granted for this version to appear in e-Publications@Marquette. Emerald does not grant permission for this article to be further copied/distributed or hosted elsewhere without the express permission from Emerald. 
In spite of the extensive work already done in litigation, a number of issues remain either unaddressed or only partially examined. Hence, they represent an exceptionally attractive opportunity for future research. For instance, little work has been done regarding international litigation and how patterns observed in US corporate lawsuits differ globally. Especially interesting in this regard is how national culture might affect both the incidence and the outcomes of business litigation.

Corporate governance determines the degree to which its managers are monitored and how the firm makes its strategic decisions. Consequently, when governance systems fail and a lawsuit is initiated, the firm's directors and executives automatically become defendant in the suit. Thus, there are abundant research opportunities to investigate the influence that corporate governance structures exert on the decision to litigate, the resolution of that litigation and how the settlements are satisfied.

Because of the magnitude of the settlements and the changes in corporate strategy that litigation involves, these lawsuits can exert a long-term effect on the value and operations of a firm. Litigation can effect corporate decisions about merger and acquisition, capital expenditures, R\&D, and even dividends. The long-term financial and operating effects of litigation represents yet another stream of inquiry for future researchers.

Litigation is often the result of investor attention and the result of media coverage. Recent work by Abdulmanova et al. (2016) use a novel measure of investor attention to explain when lawsuits are filed and the market's reaction to such filings. The use of social media and other internet-based software to follow corporate activities represents yet another direction for the future study of corporate litigation.

Notes

${ }^{1}$ Audit analytics and litigation cost survey of major companies, US Chamber Institute for Legal Reform, 2010.

Managerial Finance, Vol 43, No. 1 (2017): pg. 4-18. DOI. This article is @ Emerald and permission has been granted for this version to appear in e-Publications@Marquette. Emerald does not grant permission for this article to be further copied/distributed or hosted elsewhere without the express permission from Emerald. 
NOT THE PUBLISHED VERSION; this is the author's final, peer-reviewed manuscript. The published version may be

accessed by following the link in the citation at the bottom of the page.

${ }^{2}$ Similarly, Cornerstone Research reports an average settlement for security class action lawsuits of $\$ 47$ million for the 1996-2014 period.

${ }^{3}$ Sections 12 and 10(b) similarly apply to both direct and aftermarket purchasers. However, damages under both these sections are based on the investor's purchase price rather than the offer price.

${ }^{4}$ As explained by Lowry and Shu (2002) "Under the litigation-risk hypothesis, initial returns can be related to the probability of a lawsuit along two dimensions. First, firms with higher litigation risk should underprice their IPOs by a greater amount as insurance against litigation. This implies that initial returns are an increasing function of litigation risk. Second, firms that buy more insurance against litigation, i.e., underprice more, expect to be sued less often. This implies that litigation is a decreasing function of initial returns. Because the probability of being sued is itself an endogenous variable that could depend on underpricing, a comparison of initial returns across sued and non-sued firms is problematic."

\section{References}

Abdulmanova, A. (2016), "The value of political influence in corporate litigation", working paper, University of Missouri, Columbia.

Abdulmanova, A., Lothari, P., Ferris, S. and Jayaraman, N. (2016), "The effect of investor attention on the corporate litigation process", working paper, University of Missouri, Columbia.

Adhikari, B.K., Agrawal, A. and Malm, J. (2016), "Do women stay out of trouble? Evidence from corporate litigation", working paper, University of Miami, Miami, FL.

Agrawal, A., Jaffe, J.F. and Karpoff, J.M. (1999), “Management turnover and governance changes following the revelation of fraud", The J ournal of Law and Economics, Vol. 42 No. 1, pp. 309-342.

Alexander, J.C. (1991), "Do the merits matter? A study of settlements in securities class actions", Stanford Law Review, Vol. 43 No. 3, pp. 497598.

Ali, A. and Kallapur, S. (2001), "Securities price consequences of the Private Securities Litigation Reform Act of 1995 and related events", The Accounting Review, Vol. 76 No. 3, pp. 431-460.

Managerial Finance, Vol 43, No. 1 (2017): pg. 4-18. DOI. This article is @ Emerald and permission has been granted for this version to appear in e-Publications@Marquette. Emerald does not grant permission for this article to be further copied/distributed or hosted elsewhere without the express permission from Emerald. 
Arena, M. and Julio, B. (2015), "The effects of securities class action litigation on corporate liquidity and investment policy", Journal of Financial and Quantitative Analysis, Vol. 50 Nos 1-2, pp. 251-275.

Arena, M. and Julio, B. (2016), "Litigation risk management through payout policy", working paper, Marquette University, Milwaukee, WI.

Arena, M.P. and Ferris, S.P. (2016), "Litigation risk and corporate financial policies around the world", working paper, Marquette University, Milwaukee, WI.

Autore, D.M., Hutton, I., Peterson, D.R. and Smith, A.H. (2014), "The effect of securities litigation on external financing", Journal of Corporate Finance, Vol. 27, pp. 231-250.

Bajaj, M., Caswell, N., Goel, A., Maxumdar, S.C. and Surana, R. (2014), "The real costs of US securities class action litigation", US Chamber Institute for Legal Reform

Baker, T. and Griffith, S.J . (2007), "Predicting corporate governance risk: evidence from the directors' and officers' liability insurance market", Chicago Law Review, Vol. 74 No. 2, pp. 487-544.

Banerjee, S., Humphery-J enner, M., Nanda, V.K. and Tham, T.M. (2016), "Executive overconfidence and securities class actions", working paper, University of Texas Dallas, Dallas, TX.

Banerjee, S., Dai, L. and Shrestha, K. (2011), "Cross-country IPOs: what explains differences in underpricing?", J ournal of Corporate Finance, Vol. 17 No. 5, pp. 1289-1305.

Becht, M., Bolton, P. and Röell, A. (2003), "Corporate governance and control", in Constantinides, G.M., Harris, M. and Stulz, R.M. (Eds), Handbook of the Economics of Finance, Vol. 1, Part A, Elsevier, New York, NY, pp. 1-109.

Bhagat, S., Bizjak, J. and Coles, J.L. (1998), "The shareholder wealth implications of corporate lawsuits", Financial Management, Vol. 27 No. 4, pp. 5-27.

Bhagat, S., Brickley, J.A. and Coles, J.L. (1994), "The costs of inefficient bargaining and financial distress: evidence from corporate lawsuits", Journal of Financial Economics, Vol. 35 No. 2, pp. 221-247.

Bhattacharya, U., Galpin, N. and Haslem, B. (2007), "The home court advantage in international corporate litigation", J ournal of Law and Economics, Vol. 50 No. 4, pp. 625-660.

Bizjak, J.M. and Coles, J.L. (1995), "The effect of private antitrust litigation on the stockmarket valuation of the firm", American Economic Review, Vol. 85 No. 3, pp. 436-461.

Black, B.S., Cheffins, B.R. and Klausner, M. (2006), "Outside director liability: a policy analysis", J ournal of Institutional and Theoretical Economics, Vol. 162 No. 1, pp. 5-20.

Managerial Finance, Vol 43, No. 1 (2017): pg. 4-18. DOI. This article is (C) Emerald and permission has been granted for this version to appear in e-Publications@Marquette. Emerald does not grant permission for this article to be further copied/distributed or hosted elsewhere without the express permission from Emerald. 
Bradley, D., Cline, B.N. and Lian, Q. (2014), "Class action lawsuits and executive stock option exercise", Journal of Corporate Finance, Vol. 27, pp. 157-172.

Bradley, M. and Chen, D. (2011), "Corporate governance and the cost of debt: evidence from director limited liability and indemnification provisions", Journal of Corporate Finance, Vol. 17 No. 1, pp. 83-107.

Brown, S., Hillegeist, S.A. and Lo, K. (2005), "Management forecasts and litigation risk", working paper, Sauder School of Business, University of British Columbia, Vancouver.

Cao, Z. and Narayanamoorthy, G.S. (2011), "The effect of litigation risk on management earnings forecasts", Contemporary Accounting Research, Vol. 28 No. 1, pp. 125-173.

Cao, Z. and Narayanamoorthy, G.S. (2014), "Accounting and litigation risk: evidence from directors' and officers' insurance pricing", Review of Accounting Studies, Vol. 19 No. 1, pp. 1-42.

Chandra, U., Wasley, C.E. and Waymire, G.B. (2004), "Income conservatism in the US Technology sector", working paper, Simon Business School, University of Rochester, Rochester, NY.

Chava, S., Agnes Cheng, C.S., Huang, H. and Lobo, G.J . (2010), "Implications of securities class actions for cost of equity capital", International Journal of Law and Management, Vol. 52 No. 2, pp. 144-161.

Cheng, C.A., Huang, H.H., Li, Y. and Lobo, G. (2010), "Institutional monitoring through shareholder litigation", Journal of Financial Economics, Vol. 95 No. 3, pp. 356-383.

Choi, S. (2006), "Do the merits matter less after the private securities litigation reform act?", The Journal of Law, Economics, and Organization, Vol. 23 No. 3, pp. 598-626.

Correia, M. (2014), "Political connections and SEC enforcement", Journal of Accounting and Economics, Vol. 57 Nos 2-3, pp. 241-262.

Cox, J.D. and Thomas, R.S. (2004), "Public and private enforcement of the securities laws: have things changed since enron?", Notre Dame Law Review, Vol. 80 No. 3, pp. 893-907.

Cutler, D.M. and Summers, L.H. (1988), "The costs of conflict resolution and financial distress: evidence from the Texaco-Pennzoil litigation", The Rand Journal of Economics, Vol. 19 No. 2, pp. 157-172.

Dai, Z., J in, L. and Zhang, W. (2014), "Executive pay - performance sensitivity and litigation", Contemporary Accounting Research, Vol. 31 No. 1, pp. 152-177.

Daines, R., Gow, I. and Larcker, D. (2010), "Rating the ratings: how good are commercial corporate governance ratings?", Journal of Financial Economics, Vol. 98 No. 3, pp. 439-461.

Dechow, P.M., Sloan, R.G. and Sweeney, A.P. (1996), "Causes and consequences of earnings manipulation: an analysis of firms subject to

Managerial Finance, Vol 43, No. 1 (2017): pg. 4-18. DOI. This article is @ Emerald and permission has been granted for this version to appear in e-Publications@Marquette. Emerald does not grant permission for this article to be further copied/distributed or hosted elsewhere without the express permission from Emerald. 
enforcement actions by the SEC", Contemporary Accounting Research, Vol. 13 No. 1, pp. 1-36.

Deng, S., Willis, R.H. and Xu, L. (2014), "Shareholder litigation, reputational loss, and bank loan contracting", Journal of Financial and Quantitative Analysis, Vol. 49 No. 4, pp. 1101-1132.

Donelson, D.C., Mclnnis, J.M., Mergenthaler, R.D. and Yu, Y. (2012), "The timeliness of bad earnings news and litigation risk", The Accounting Review, Vol. 87 No. 6, pp. 1967-1991.

Drake, P.D. and Vetsuypens, M.R. (1993), “IPO underpricing and insurance against legal liability", Financial Management, Vol. 22 No. 1, pp. 6473.

DuCharme, L.L., Malatesta, P.H. and Sefcik, S.E. (2004), “Earnings management, stock issues, and shareholder lawsuits", J ournal of Financial Economics, Vol. 71 No. 1, pp. 27-49.

Dyl, E.A. (1999), "Estimating economic damages in class action securities fraud litigation", J ournal of Forensic Economics, Vol. 12 No. 1, pp. 111.

Ellert, J.C. (1976), “Mergers, antitrust law enforcement and stockholder returns", The Journal of Finance, Vol. 31 No. 2, pp. 715-732.

Engelmann, K. and Cornell, B. (1988), "Measuring the cost of corporate litigation: five case studies", The Journal of Legal Studies, Vol. 17 No. 2, pp. 377-399.

Farber, D.B. (2005), "Restoring trust after fraud: does corporate governance matter?", The Accounting Review, Vol. 80 No. 2, pp. 539-561.

Ferris, S., Hao, G. and Liao, M. (2013), "The effect of issuer conservatism on IPO pricing and performance", Review of Finance, Vol. 17 No. 3, pp. 993-1027.

Ferris, S.P. and Pritchard, A.C. (2001), "Stock price reactions to securities fraud class actions under the private securities litigation reform act", Michigan Law and Economics Research Paper, No. 01-009, University of Michigan, Ann Arbor, MI.

Ferris, S.P., Jandik, T., Lawless, R.M. and Makhija, A. (2007), “Derivative lawsuits as a corporate governance mechanism: empirical evidence on board changes surrounding filings", J ournal of Financial and Quantitative Analysis, Vol. 42 No. 1, pp. 143-165

Fich, E.M. and Shivdasani, A. (2007), "Financial fraud, director reputation, and shareholder wealth", J ournal of Financial Economics, Vol. 86 No. 2, pp. 306-336.

Field, L., Lowry, M. and Shu, S. (2005), “Does disclosure deter or trigger litigation?", Journal of Accounting and Economics, Vol. 39 No. 3, pp. 487-507.

Managerial Finance, Vol 43, No. 1 (2017): pg. 4-18. DOI. This article is @ Emerald and permission has been granted for this version to appear in e-Publications@Marquette. Emerald does not grant permission for this article to be further copied/distributed or hosted elsewhere without the express permission from Emerald. 
Firth, M., Rui, O. and Wu, W. (2011), "The effects of political connections and state ownership on corporate litigation in China", The J ournal of Law and Economics, Vol. 54 No. 3, pp. 573-607.

Fischel, D.R. and Bradley, M. (1986), "Role of liability rules and the derivative suit in corporate law: a theoretical and empirical analysis", Cornell Law Review, Vol. 71 No. 2, pp. 261-298.

Francis, J., Philbrick, D. and Schipper, K. (1994a), "Determinants and outcomes in class action securities litigation", working paper, University of Chicago, Chicago, IL.

Francis, J., Philbrick, D. and Schipper, K. (1994b), "Shareholder litigation and corporate disclosures", Journal of Accounting Research, Vol. 32 No. 2, pp. 137-164.

Fulmer, S. and Knill, A.M. (2013), "Political contributions and the severity of government enforcement", working paper, Florida State University, Tallahassee.

Gande, A. and Lewis, C.M. (2009), "Shareholder-initiated class action lawsuits: shareholder wealth effects and industry spillovers", J ournal of Financial and Quantitative Analysis, Vol. 44 No. 4, pp. 823-850.

Gormley, T.A. and Matsa, D.A. (2011), "Growing out of trouble? Corporate responses to liability risk", Review of Financial Studies, Vol. 24 No. 8, pp. 2781-2821.

Griffin, P.A., Grundfest, J.A. and Perino, M.A. (2004), "Stock price response to news of securities fraud litigation: an analysis of sequential and conditional information", Abacus, Vol. 40 No. 1, pp. 21-48.

vate Securities Litigation Reform Act of 1995", Stanford University, Stanford, CA.

Hanley, K.W. and Hoberg, G. (2012), “Litigation risk, strategic disclosure and the underpricing of initial public offerings", J ournal of Financial Economics, Vol. 103 No. 2, pp. 235-254.

Hao, Q. (2011), "Securities litigation, withdrawal risk and initial public offerings", J ournal of Corporate Finance, Vol. 17 No. 3, pp. 438-456.

Helland, E. (2006), "Reputational penalties and the merits of class-action securities litigation", J ournal of Law and Economics, Vol. 49 No. 2, pp. 365-395.

Hensler, D.A. (1995), "Litigation costs and the underpricing of initial public offerings", Managerial and Decision Economics, Vol. 16 No. 2, pp. 111128.

Hughes, P.J . and Thakor, A.V. (1992), "Litigation risk, intermediation, and the underpricing of initial public offerings", Review of Financial Studies, Vol. 5 No. 4, pp. 709-742.

Humphery-J enner, M.L. (2012), "Internal and external discipline following securities class actions", J ournal of Financial Intermediation, Vol. 21 No. 1, pp. 151-179.

Managerial Finance, Vol 43, No. 1 (2017): pg. 4-18. DOI. This article is @ Emerald and permission has been granted for this version to appear in e-Publications@Marquette. Emerald does not grant permission for this article to be further copied/distributed or hosted elsewhere without the express permission from Emerald. 
Hutton, I., Jiang, D. and Kumar, A. (2015), "Political values, culture, and corporate litigation", Management Science, Vol. 61 No. 12, pp. 29052925

Ibbotson, R.G. (1975), "Price performance of common stock new issues", Journal of Financial Economics, Vol. 2 No. 3, pp. 235-272.

I qbal, Z., Shetty, S. and Wang, K. (2007), "Further evidence on insider trading and the merits of securities class actions", J ournal of Financial Research, Vol. 30 No. 4, pp. 533-545.

Jarrell, G. and Peltzman, S. (1985), "The impact of product recalls on the wealth of sellers", Journal of Political Economy, Vol. 93 No. 3, pp. 512536

Johnson, M.F., Kasznik, R. and Nelson, K.K. (2000a), "Shareholder wealth effects of the Private Securities Litigation Reform Act of 1995", Review of Accounting Studies, Vol. 5 No. 3, pp. 217-233

Johnson, M.F., Kasznik, R. and Nelson, K.K. (2001), "The impact of securities litigation reform on the disclosure of forward-looking information by high technology firms", J ournal of Accounting Research, Vol. 39 No. 2, pp. 297-327.

Jonson, M.F., Nelson, K.K. and Pritchard, A.C. (2000b), “In re silicon graphics securities litigation: shareholder wealth effects of the interpretation of the private Securities Litigation Reform Act's pleading standard", Southern California Law Review, Vol. 73 No. 4, pp. 773-810.

Johnson, M.F., Nelson, K.K. and Pritchard, A.C. (2007), "Do the merits matter more? The impact of the private securities litigation reform Act", Journal of Law, Economics, and Organization, Vol. 23 No. 3, pp. 627652.

Jones, C.L. and Weingram, S.E. (1996), "The determinants of 10b-5 litigation risk", George Washington University, Washington, DC.

Karpoff, J. and Lott, J . (1999), "On the determinants and importance of punitive damage awards", The Journal of Law and Economics, Vol. 42 No. S1, pp. 527-573.

Karpoff, J., Lee, D. and Martin, G. (2008a), "The cost to firms of cooking the books", Journal of Financial and Quantitative Analysis, Vol. 43 No. 3, pp. 581-612.

Karpoff, J.M. and Lott, J.R. (1993), "The reputational penalty firms bear from committing criminal fraud", J ournal of Law and Economics, Vol. 36 No. 2, pp. 757-802

Karpoff, J.M., Lee, D.S. and Martin, G.S. (2008b), "The consequences to managers for financial misrepresentation", J ournal of Financial Economics, Vol. 88 No. 2, pp. 193-215.

Keloharju, M. (1993), “The winner's curse, legal liability, and the long-run price performance of initial public offerings in Finland", J ournal of Financial Economics, Vol. 34 No. 2, pp. 251-277.

Managerial Finance, Vol 43, No. 1 (2017): pg. 4-18. DOI. This article is @ Emerald and permission has been granted for this version to appear in e-Publications@Marquette. Emerald does not grant permission for this article to be further copied/distributed or hosted elsewhere without the express permission from Emerald. 
Kim, I. and Skinner, D.J. (2012), "Measuring securities litigation risk", J ournal of Accounting and Economics, Vol. 53 No. 1, pp. 290-310.

Klein, B. and Leffler, K.B. (1981), "The role of market forces in assuring contractual performance", The Journal of Political Economy, Vol. 89 No. 4, pp. 615-641.

Klock, M. (2015), "Do class action filings affect stock prices? The stock market reaction to securities class actions post PSLRA", J ournal of Business and Securities Law, Vol. 15 No. 1, pp. 109-219.

Landes, W.M. and Posner, R.A. (1987), "Trademark law: an economic perspective", The American Economic Review, Vol. 30 No. 2, pp. 265309.

Lin, H.L., Pukthuanthong, K. and Walker, T.J. (2013), “An international look at the lawsuit avoidance hypothesis of IPO underpricing", J ournal of Corporate Finance, Vol. 19, pp. 56-77.

Lowry, M. and Shu, S. (2002), "Litigation risk and IPO underpricing", J ournal of Financial Economics, Vol. 65 No. 3, pp. 309-335.

McTier, B.C. and Wald, J.K. (2011), "The causes and consequences of securities class action litigation", J ournal of Corporate Finance, Vol. 17 No. 3, pp. 649-665.

Marciukaityte, D., Szewczyk, S.H., Uzun, H. and Varma, R. (2006), "Governance and performance changes after accusations of corporate fraud", Financial Analysts Journal, Vol. 62 No. 3, pp. 32-41.

Murphy, D.L., Shrieves, R.E. and Tibbs, S.L. (2009), “Understanding the penalties associated with corporate misconduct: an empirical examination of earnings and risk", J ournal of Financial and Quantitative Analysis, Vol. 44 No. 1, pp. 55-83.

Niehaus, G. and Roth, G. (1999), "Insider trading, equity issues, and CEO turnover in firms subject to securities class action", Financial Management, Vol. 28 No. 4, pp. 52-72.

Peltzman, S. (1981), "The effects of FTC advertising regulation", The American Economic Review, Vol. 24 No. 3, pp. 403-448.

Peng, L. and Röell, A. (2008), "Manipulation and equity-based compensation", American Economic Review, Vol. 98 No. 2, pp. 285-290.

Perino, M.A. (2003), "Did the private securities litigation reform act work?", University of Illinois Law Review, Vol. 2003 No. 4, pp. 913-978.

Phillips, R.M. and Miller, G.C. (1996), "The Private Securities Litigation Reform Act of 1995: rebalancing litigation risks and rewards for class action plaintiffs, defendants and lawyers", The Business Lawyer, Vol. 51 No. 4, pp. 1009-1069

Rogers, J.L. and Stocken, P.C. (2005), "Credibility of management forecasts", The Accounting Review, Vol. 80 No. 4, pp. 1233-1260.

Managerial Finance, Vol 43, No. 1 (2017): pg. 4-18. DOI. This article is @ Emerald and permission has been granted for this version to appear in e-Publications@Marquette. Emerald does not grant permission for this article to be further copied/distributed or hosted elsewhere without the express permission from Emerald. 
Rogers, J.L. and Van Buskirk, A. (2009), "Shareholder litigation and changes in disclosure behaviour", J ournal of Accounting and Economics, Vol. 47 No. 1, pp. 136-156.

Rogers, J.L., Van Buskirk, A. and Zechman, S.L. (2011), “Disclosure tone and shareholder litigation", The Accounting Review, Vol. 86 No. 6, pp. 2155-2183.

Romano, R. (1991), "The shareholder suit: litigation without foundation?", Journal of Law, Economics, and Organization, Vol. 7 No. 1, pp. 55-87.

Simmons, R.W. and Hoyt, R.C. (1993), "Economic damage analysis in rule 10b-5 securities litigations", J ournal of Legal Economics, Vol. 3 No. 1, pp. 71-87.

Skinner, D.J. (1994), "Why firms voluntarily disclose bad news", Journal of Accounting Research, Vol. 32 No. 1, pp. 38-60.

Skinner, D.J. (1997), "Earnings disclosures and stockholder lawsuits", J ournal of Accounting and Economics, Vol. 23 No. 3, pp. 249-282.

Tinic, S.M. (1988), "Anatomy of initial public offerings of common stock", The Journal of Finance, Vol. 43 No. 4, pp. 789-822.

Walker, T., Turtle, H.J., Pukthuanthong, K. and Thiengtham, D. (2015), “Legal opportunism, litigation risk, and IPO underpricing", J ournal of Business Research, Vol. 68 No. 2, pp. 326-340.

Yuan, Q. and Zhang, Y. (2015), "Do banks price litigation risk in debt contracting? Evidence from class action lawsuits", J ournal of Business Finance and Accounting, Vol. 42 Nos 9-10, pp. 1310-1340.

Zhu, Y.E. (2009), "The relation between IPO underpricing and litigation risk revisited: changes between 1990 and 2002", Financial Management, Vol. 38 No. 2, pp. 323-355.

Zingales, L. (2007), "Is the US capital market losing its competitive edge?", ECGI-Finance working paper, European Corporate Governance Institute, No. 192/1997, University of Chicago, Chicago, IL.

Managerial Finance, Vol 43, No. 1 (2017): pg. 4-18. DOI. This article is (C) Emerald and permission has been granted for this version to appear in e-Publications@Marquette. Emerald does not grant permission for this article to be further copied/distributed or hosted elsewhere without the express permission from Emerald. 